\title{
THE DIFFERENCES IN ACUPUNCTURE THERAPY AND KATUK LEAF EXTRACT ON BREAST MILK PRODUCTION IN BREASTFEEDING MOTHERS IN DUWETAN NGUNUT JUMANTONO KARANGANYAR
}

\author{
Imrok Atus Sholihah*, Sri Widyastari \\ Acupuncture Department, Potekkes Kemenkes Surakarta, Jl. Letjen Sutoyo, Mojosongo Jebres Surakarta, \\ Indonesia \\ * Corresponding author
}

E-mail: imrokatussholihah6@gmail.com

\begin{abstract}
Background: Suboptimal breastfeeding accounts for $45 \%$ of deaths. Various treatments can be done to increase the amount of breast milk production, both pharmacological and nonpharmacological. One of the efforts that can be done to increase the rate of secretion and production of breast milk is through the use of traditional herbal medicines such as katuk extract (Sauropus androgynus). Acupuncture significantly improves exclusive breastfeeding. Acupuncture therapy can be done to increase the hormone prolactin in breastfeeding.

Objective: To determine the difference between acupuncture therapy and katuk leaf extract on increasing breast milk production in breastfeeding mothers in Duwetan, Ngunut, Jumantono, Karanganyar. Time and Place: April-May 2021, at Duwetan, Ngunut, Jumantono, Karanganyar. Subjects: The research sample taken was 40 mothers who were in the breastfeeding phase in Duwetan, Ngunut, Jumantono, Karanganyar.

Methods: This study is a experimental study with a Pretest-Posttest Control Group design. Statistical test using univariate analysis and bivariate analysis using independent $t$-test

Results: After the intervention, milk production (based on baby's weight) in the acupuncture group was higher $(\mathrm{Mean}=4.029,50 ; \mathrm{SD}=392,33)$ than in the katuk leaf extract group (Mean=3.450,50; $\mathrm{SD}=405,08$ ). There was a difference in breast milk production in the acupuncture group and the katuk leaf extract group $(\mathrm{p}<0,001)$. The administration of acupuncture increased milk production significantly with an effect value $(\mathrm{ES}=1,45)$ compared to the administration of katuk leaf extract.
\end{abstract}

Conclusion: There is a difference between acupuncture therapy and katuk leaf extract on breast milk production in breastfeeding mothers.

Keywords: Acupuncture, katuk leaf extract, Breast Milk Production 


\begin{abstract}
INTRODUCTION
Suboptimal breastfeeding was accounted for $45 \%$ of deaths due to neonatal infectious diseases, 30\% of deaths due to diarrhea, and $18 \%$ of deaths due to acute respiratory disorders in children under five. The death of 30,000 children in Indonesia every year can be prevented by exclusive breastfeeding (Air Susu Ibu) which can reduce infant mortality by $13 \%^{[1]}$
\end{abstract}

Breast milk is one of the perfect and best foods for babies because it contains the nutritional elements needed by babies for optimal growth and development. ${ }^{2}$ The government's followup to increase the coverage of exclusive breastfeeding with Government Regulation (PP) number 33 of 2012 regarding exclusive breastfeeding is contained in article 6 which reads that "Each mother gives birth to exclusive breast milk for 6 months" ${ }^{\text {[3] }}$.

Various treatments can be done to increase the amount of breast milk production, both pharmacological and non-pharmacological. ${ }^{4}$ One of the efforts that can be done to increase the rate of secretion and production of breast milk is through the use of traditional herbal medicines such as katuk leaf extract (Sauropus androgynus). Katuk leaf (Saoropus androgynus) has been known in traditional medicine in South and Southeast Asia as a medicine to increase breast milk. Katuk leaves can be consumed easily, katuk leaves can be boiled and produced as phytopharmaca which is efficacious to launch breast milk. $^{5}$

\footnotetext{
Acupuncture significantly increases exclusive breastfeeding, besides acupuncture is a method that can be used to reduce breast engorgement in mothers. ${ }^{6}$ Acupuncture therapy helps smooth energy, blood circulation, lymph flow and nervous system so that it can affect the mechanism of action of
}

hormones. Acupuncture therapy can be done to increase the hormone prolactin in breastfeeding ${ }^{[7]}$.

This study aims to determine the difference between groups given acupuncture therapy and groups given katuk leaf extract to increase milk production in breastfeeding mothers in Duwetan, Ngunut, Jumantono, Karanganyar.

\begin{tabular}{cc}
\hline METHODS \\
\hline This research design is a
\end{tabular}
quantitative research using experimental design with Pretest-Posttest Control Group design. This research was conducted pretest to determine the initial state of the subject under study (before being given the intervention) and post-test (after being given the intervention) whose results can be compared or seen the changes. The independent variables were acupuncture therapy and katuk leaf extract.

The population in this study were breastfeeding mothers in Duwetan, Ngunut, Jumantono, Karanganyar. The sampling technique was purposive sampling with 40 respondents with inclusion criteria, namely exclusive breastfeeding mothers who had babies aged 0-6 months. Data collection was carried out in April-May 2021. Data collection using observation sheets consisted of 1) intervention of acupuncture therapy at point $C V \quad 17$ Danzhong (location: on the medialis sagitalis line, between the two mammae papillae as high as between ribs IV), SP 6 Sanyinjiao (location: 3 cun proximal prominens maleolus medialis, right on the posterior edge of the os tibia), ST 18 Rugen (location: on the rib gap V, 2 fingers under the mammary papila), 2) the intervention of giving katuk leaf extract. Each research subject was observed for three weeks.

The steps for giving acupuncture therapy are cleaning the puncture area with $70 \%$ alcohol cotton, performing stabbing 
at the points $\mathrm{CV}-17$, SP-6, and ST-18, then cleaning again with alcohol cotton. The step of giving katuk leaf extract is to give 10 grains of katuk leaf extract taken 3 times a week.
This research was conducted with univariate analysis, Shapiro-Wilk, and independent t-test analysis.

\section{RESULTS}

The results of this study can be seen in the following table:

Table 1. Characteristics of Research Subjects

\begin{tabular}{lccccc}
\hline \multicolumn{1}{c}{ Characteristics } & $\mathrm{n}$ & Mean & SD & Min. & Maks. \\
\hline Mother's age (years) & 40 & 24,70 & 4,35 & 18 & 37 \\
Infant's age (months) & 40 & 2,63 & 0,70 & 2 & 4 \\
$\begin{array}{l}\text { Baby's weight before } \\
\text { intervention (grams) }\end{array}$ & 40 & $3.177,50$ & 354,31 & 2.520 & 3.800 \\
$\begin{array}{l}\text { Baby's weight after } \\
\text { intervention (grams) }\end{array}$ & 40 & $3.740,00$ & 490,80 & 2.950 & 4.700 \\
Infant's weight gain (grams) & 40 & 562,50 & 294,50 & 150 & 1.100 \\
\hline
\end{tabular}

Table 1 shows that the study sample had an average age of 25 years and an average infant of 3 months. The results of the measurement of breast milk production were based on the average baby weight before the intervention was 3,177.50 grams, the average baby weight after the intervention was 3,740 grams, and the average baby weight gain for three weeks was 562.50 grams.

Table 2. The difference in the average milk production based on the baby's weight in the acupuncture and katuk leaf extract groups

\begin{tabular}{lccccc}
\hline \multicolumn{1}{c}{ Variabel } & $\mathrm{n}$ & Mean & SD & $\mathrm{p}$ & Effect Size \\
\hline Before intervention (grams) & & & & & \\
Acupuncture & 20 & $3.227,50$ & 344,21 & 0,379 & 0,28 \\
Katuk leaf extract & 20 & $3.127,50$ & 365,97 & & \\
After intervention (grams) & & & & & \\
Acupuncture & 20 & $4.029,50$ & 392,33 & $<0,001$ & 1,45 \\
Katuk leaf extract & 20 & $3.450,50$ & 405,08 & & \\
\hline
\end{tabular}

Table 2 shows that there is no statistically significant difference in the volume of breast milk production before intervention $(p=0.379)$. The findings showed that randomization was successful in making the two groups comparable in volume of breast milk production before the intervention. By randomization, each nursing mother had an equal chance of being selected into the acupuncture group and the katuk leaf extract group. After the intervention, the average milk production (based on baby's weight) in the acupuncture group was higher (Mean=4,029; $\mathrm{SD}=392,33)$ than the katuk leaf extract group (Mean=3,450.50; $\mathrm{SD}=$ 405.08). These results showed that there were differences in breast milk production after acupuncture intervention and katuk leaf extract were statistically significant ( $p$ $<0.001$ ). The table above also shows that giving acupuncture therapy increased milk production in nursing mothers with an effect value $(E S=1.45)$ compared to giving katuk leaf extract.

\section{DISCUSSION}

These results indicate that there is an increase in the average volume of breast milk production before and after the 
intervention in the acupuncture group and the katuk leaf extract group. The average milk production (baby weight) before the intervention in the acupuncture group was $3,227.50$ grams, then increased to 4,029.50 grams after being given acupuncture intervention. The average milk production (baby weight) before the intervention in the katuk leaf extract group was 3,127.50 grams, then increased to $3,450.50$ grams after being given the katuk leaf extract intervention.

Katuk leaves have a high iron content and are rich in vitamins (A, B1, and $\mathrm{C}$ ), protein, fat, and minerals. Katuk leaves also contain tannins, saponins, flavonoids, and papaverine alkaloids, so they have the potential to be used as traditional medicinal ingredients. The compound in katuk leaves that plays a role in promoting breast milk is sesquiterna acid ${ }^{[8]}$. The production and expenditure of breast milk is influenced by 2 hormones, namely prolactin and oxytocin. Prolactin affects the amount of milk production, while oxytocin affects the process of expulsion of breast milk. Prolactin is related to maternal nutrition, the better the nutritional intake, the more milk production ${ }^{[9]}$.

Katuk leaves also contain polyphenyls and steroids which play a role in increasing prolactin or stimulating the alveoli to produce breast milk, as well as stimulating the hormone oxytocin to stimulate milk production. Katuk leaves also contain several aliphatic compounds. The efficacy of katuk leaves as an increase in breast milk production is thought to come from the hormonal effects of sterol chemical compounds which are estrogenic $^{[10]}$.

Previous research by Sa'roni et al, (2004) explained that giving katuk leaf extract to the group of mothers giving birth and breastfeeding at a dose of $3 \times 300$ $\mathrm{mg} /$ day for 15 days starting from day 3 after giving birth can increase milk production $50.7 \%$ more compared to mothers giving birth and breastfeeding their babies who were not given katuk leaf extract, giving katuk leaf extract could reduce the number of subjects with less milk production by $12.5 \% 0^{[5]}$.

According to the principles of Traditional Chinese Medicine (TCM), postpartum hypogalactia is mainly caused by $q i$ and blood deficiency or liver $q i$ stagnation. Deficiency of qi and blood leads to insufficient milk production and liver qi stagnation causes coagulation or blockage of breast milk. A systematic review concluded that acupuncture and acupressure were effective in increasing breast milk volume ${ }^{[11]}$. The results of this study are also in line with Neri et al., (2011) which states that acupuncture techniques are effective in increasing breast milk production. Breast milk production is the volume of breast milk measured for 7 days using a measuring cup. The average volume of milk production per day has increased ${ }^{[12]}$.

Several other studies described performing acupuncture at CV 17 (also referred to as Ren 17. Danzhong or Shanzong; located in the middle of the sternum), SI 1 (Shaoze; on the little finger), ST 18 (Rugen; lower breast margin), Zusanli (ST 36), and Taichong (LR 3) are beneficial for women with low milk production postpartum ${ }^{[13]}$.

The two complementary treatments, namely acupuncture and katuk leaf extract were very effective in increasing breast milk production in nursing mothers, but in this study it was shown that there was a difference in breast milk production (baby weight) in the acupuncture group and the katuk leaf extract group $(\mathrm{p}<0.001)$. Giving acupuncture therapy increased milk production significantly with an effect value $(\mathrm{ES}=1.45)$ compared to giving katuk leaf extract.

This can be seen from the preparation for increasing breastfeeding, namely the condition of the mother, especially self-efficacy. Self-efficacy is the mother's belief in her ability to breastfeed 
her baby. This affects the mother's response to infant feeding (effort and thought), which in turn affects breastfeeding initiation and maintaining positive breastfeeding behavior. Breastfeeding self-efficacy increases the coverage of exclusive breastfeeding. It shows that self-efficacy is an effective theory of social change to increase the rate of exclusive breastfeeding. Physiological responses/affective states such as anxiety, stress, depression, fatigue, and pain can affect a person's self-efficacy. Mothers who are relaxed and calm will have higher self-efficacy than mothers who are stressed, anxious or feeling sick ${ }^{[14]}$.

According to Jogde and Bhore (2013) that the smooth production and flow of breast milk (ASI) is often influenced by several factors such as stress, anxiety, fatigue, dehydration and nutrition $^{[15]}$. These conditions can be minimized by using acupuncture and relaxation acupressure. According to the Indonesian Ministry of Health, the Directorate of Traditional, Alternative and Complementary Health Services (2012) explains that one way to increase breast milk production is acupuncture, especially lactapuncture or maternal massage. Lactapuncture massage is one method that is still rarely used to stimulate the productivity of breast milk. Lactapuncture techniques can be applied as a complementary therapy to postpartum mothers, this therapy helps smooth energy flow, blood circulation, lymph flow and nervous system so that it can affect the workings of hormone metabolism. This therapy can be done as an effort to increase the hormone prolactin in the breastfeeding process $^{[12]}$.

Some research statistics show that DU 14, ST 18, S 11, ST 36, LR 3 are the acupoints most often used to treat the lack of milk production. This explains that the use of acupuncture needles can stimulate Heche towards the back, can suppress the mother's vital $q i$ smoothly and make the mother feel warm, relaxed, and comfortable. Pressing through the carding meridians and collaterals, can increase pleasure, relieve pain, relieve tension, and indirectly promote milk secretion and excretion $^{[6]}$.

Based on a previous study conducted by Andrew (2005), it was stated that the mechanism of a bio-chemical stimulus injected through an electrical acupoint at a meridian point would have a response four times faster by activating impulses to the brain, especially the neurohormonal complex of the pituitaryadrenocortical axis. Feedback from this mechanism is a relaxation response and lower cortisol production, which is one of the causes of hypogalactia. Relaxation is the result of the body's physiological response to acupoint stimuli, by increasing endorphins and serotonin transmission to the brain and other organs via nerves and meridians $^{[17]}$.

This explanation is supported by a meta-analysis by Mangesi (2016) that women who received acupuncture were less likely to develop abscesses, had less severe symptoms on day five, and had lower rates of fever than women in the usual care group, evidence that suggests enough of the published trials to justify widespread implementation $^{[18]}$.

The results of the above explanation can be concluded that the direct impact caused when giving acupuncture therapy is relaxation in the mother so as to increase the hormone prolactin that can launch and increase breast milk production compared to the administration of katuk leaf extract.

The limitation in the study is that researchers have not included confounding or confounding factors. Some of these factors, namely food consumption, stress levels (baby blues) and others can affect the amount of breast milk production in the mother and the baby's weight. The number of samples was still small (40 study subjects). 


\section{CONCLUSIONS}

The results of this study showed that there were differences in breast milk production in the acupuncture group and the katuk leaf extract group $(p<0,001)$. Administration of acupuncture therapy increases breast milk production quite large with an Effect value $(\mathrm{ES}=1.45)$ compared to the administration of katuk leaf extract. The community needs to add more knowledge about treatments to increase breast milk production, especially about acupuncture therapy, both looking for sources of information through books, mass media, internet media, and also to health care workers. Nursing mothers can do acupuncture therapy to relax which lead to increase breast milk production.

\section{REFERENCES}

1. Kemenkes RI (2014). Situasi Dan Analisis ASI Eksklusif. Infodatin Pusat Data Dan Informasi Kementerian Kesehatan RI: Jakarta.

2. Roesli U (2009). Inisiasi Menyusu Dini Plus ASI Eksklusif. Jakarta : Pustaka Bunda.

3. Fikawati S, Syafiq A (2009). Penyebab Keberhasilan dan Kegagalan Praktik Pemberian ASI Eksklusif. Jurnal Kesehatan Masyarakat Nasional, 4(3), 120-131.

4. Juliastuti (2019). Efektivitas Daun Katuk (Sauropus Androgynus) terhadap Kecukupan Asi pada Ibu Menyusui di Puskesmas Kuta Baro. Indonesian Journal for Health Sciences Vol.3. No.1, Maret 2019. Hal, 1-5.

5. Li D, Jiang $Y$, Ma $X$, Li Q, Chu X, Zhong W, Deng X, Yang X (2021). The effect of pestle acupuncture for patients with lactation insufficiency after cesarean section Study protocol for a randomized controlled trial. Medicine; 2021;100:3(e23808). http://dx.doi.org/10.1097/MD.000000 0000023808.
6. Yuliani NR, Larasati N, Setiwandari (2021). Peningkatan Produksi ASI Ibu Menyusui dengan Tatalaksana Kebidanan Komplementer. Prosiding Seminar Nasional Hasil Riset dan Pengabdian (SNHRP-III 2021).

7. Lestari SF, Prasetyorini H (2020). Pemberian Jus Daun Katuk untuk Kesiapan Peningkatan Pemberian ASI pada Ibu Postpartum Primipara. Jurnal Manajemen Asuhan Keperawatan; Vol. 4 No. 1 Januari 2020. Halaman 53 -60 .

8. Situmorang TS, Singarimbun AP (2019). Pengaruh Konsumsi Air Rebusan Daun Katuk terhadap Pengeluaran Produksi ASI pada Ibu Nifas di Bidan Praktek Mandiri Manurung Medan tahun 2018. Indonesian Trust Health Journal, Volume 1, No,2 - April 2019.

9. Triananinsi N, Andryani, Basri F (2020). Hubungan Pemberian Sayur Daun Katuk Terhadap Kelancaran ASI Pada Ibu Multipara Di Puskesmas Caile. Journal of Healthcare Technology and Medicine Vol. 6 No. 1 April 2020.

10. Hajian $H, \quad$ Soltani $M$, Mohammadkhani, MS, et al. (2021). The effect effecteffect of acupressure, acupuncture and massage techniques on the symptoms of breast engorgement and increased breast milk volume in lactating mothers: A systematic review. Int $J$ PediatrMashhad, 2021;9:12939-50. doi: 10.22038/ijp.2020.54458.4305.

11. Patimah S, Mashoedi ID, Hadisaputro S (2019). The Effect of Lactapuncture Massage on Breast Milk Production through Prolactin Hormone Levels Changes in Dr. M. Ashari Hospital, Pemalang, Central Java. Indonesian Journal of Medicine (2019), 4(1): 1520.https://doi.org/10.26911/theijmed. 2019.04.01.03.

12. Fan ZL, Yang MF, Yin RP, Zhongguo ZJ (2020). Exploration on the acupoint selection rule for the treatment of 
postpartum hypogalactia with acupuncture and moxibustion based on the set visualization analysis system. PubMed, 2020;40:1138-42.

13. Brockway M, Benzels K, Hayden A (2017). Interventions to Improve Breastfeeding Self-Efficacy and Resultant Breastfeeding Rates: A Systematic Review and MetaAnalysis. Journal of Human Lactation, 00(0), 1-14.

14. Asmalinda W, Lestari D (2020). Efek Kombinasi Back Massage dan Acupoint Massage terhadap Peningkatan Kadar Prolaktin. Jurnal Kesehatan, Volume 11, Nomor 2, Tahun 2020, hlm 230-235.

15. Arumsari DR, Indrawan IWA, Wahyuni ES (2018). The Combination of Acupressure and Affirmation Relaxation as an Alternative Method to Increase Breast Milk Production and Breastfeeding Self-efficacy. Research Journal of Life Science, APRIL-2018 Volume 5 NO, 1 (66-76).

16. Maula SN, Widyawati MN, Suryono (2018). A Model for Hypogalactia Treatment Using Electrical Acupoint to Increase Breast Milk Volume and Improve Prolactin Content. E3S Web of Conferences. https://doi.o rg/10.1051/e3sconf/20187306020.

17. Mangesi L, Zakarija-Grkovic I (2016). Treatments for breast engorgement during lactation. Cochrane Database Syst Rev; 2016; 6:CD006946. 